\title{
ANTROPOGENICALLY CREATED FOREST EDGE IN THE STAROHORSKÉ VRCHY MTS. ON THE EXAMPLE OF DONOVALY VILLAGE
}

\author{
MARTINA ŠKODOVÁ, ALFONZ GAJdOŠ \\ Dept. of Geography, Geology and Landscape Ecology, Faculty of Natural Sciences, Matej \\ Bel University, Tajovského 40, Banská Bystrica, Slovakia, E-mail: Martina.Skodova@ \\ umb.sk, Alfonz.Gajdos@umb.sk
}

Received: $27^{\text {th }}$ August 2010, Accepted: $10^{\text {th }}$ June 2011

\begin{abstract}
Forest edges represent specific elements forming the character of landscape. They are very important factors in ecological stability. To know and to understand them as a part of dynamic and hierarchic structure in vertical and horizontal shaping of the landscape contributes to understanding of the processes between forest and non-forested landscape in connection to influence of ecological factors towards broad knowledge of the country in the shape of its utilization and monitoring of its dynamic changes. The aim of the paper is to analyze in a geographic sense the types of anthropic forest edges in the area of Starohorské vrchy Mts. (on the example of Donovaly village) and their partial geographic synthesis in the frame of chosen attributes and forest edge functions. Basic question is whether human activity influences the dynamics of environmental variables, its structure, taxonomic diversity and other attributes of forest edges.
\end{abstract}

Key words: Antropogenically created forest edge, Edge effects, Species diversity, Starohorské vrchy Mts., Donovaly village, Landscape structure

\section{INTRODUCTION}

Forest landscape in Starohorské vrchy Mts. is characterized by massive dynamics of forest stands in previous centuries. It is the result of mining and grazing. This led to fragmentation of coherent forest stands, and created anthropic forest edges. Various ways of utilization of grassland areas and forests in the past and also in present time led to the creation of forest edges with different structure. The aiml of this research is to evaluate their structure and their species diversity on the example of Donovaly village that is situated in north-east part of Starohorské vrchy Mts.

\section{AREA OF STUDY}

Field research was carried out in deforested surroundings of the Donovaly village (Fig. 1) that belongs to the group of the highest located villages in Slovakia (988 $\mathrm{m}$ a.s.1). It is located in an erosion saddle at the fault line between Vel'ká Fatra Mts. ande Starohorské 
Mountains. When forming, return stream erosion dominated (Starohorský brook, Korytnica). Geologic bottom layer consists of beds of deluvial sediments (gravels, loams). By the influence of anthropogenic activity scour erosion occurred (Gajdoš 2005). Soil is represented by eutric cambisols, only the westernmost part of the site is composed of rendzic leptosols with cambic subtype.

\section{Fig. 1: View of the saddle and Donovaly village}

(view from the top of Motyčská hol'a (1 290 a.s.1.), November 2007, photo M. Škodová)

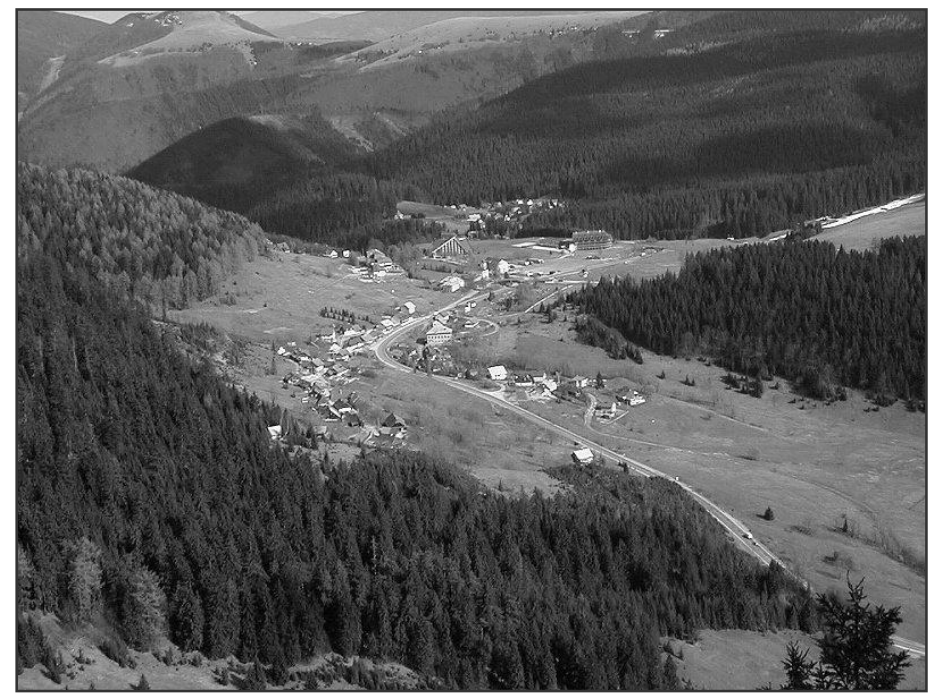

\section{MATERIAL AND METHODS}

The edge of the forest is the area between the line of the projection of crowns with respect to forest edge or growth cover (trees and shrubs cover more than $40 \%$ of the area) and the line of the first tree trunks in the main storey of the forest. The value of $2.5 \mathrm{~m}$ was added to the measured items on both sides of the ecotone which is how the edge zone of forest was established. This became the subject of our research. Field study was carried out with the method of belt transect in the individual types of forest edges. The transect $(10 \mathrm{~m}$ wide) was divided into four (or three) zones for the purpose of more detailed analysis - nonforest area, herbaceous edge, edge of forest community, forest. Within the framework of these we created phytosociological releves according to the principles of the ZürichMontpellier school in spring and summer on the area of $25 \mathrm{~m}^{2}$.

The acquired data comprise releves from the individual zones of forest edge transect, structural characteristics of forest edges and values of the properties of their abiotic complexes. Within the overall complex of data acquired from the 9 transects (D1 - D9), and 27 releves within the framework of them.

Plant species composition was described with the help of the combined scale of abundance and dominance according to Braun-Blanquet (1964). In cases where it was possible to take into account the representativeness of data obtained we classified single releves into various phytosociological classes. To classify grassland communities we used 
electronic expert system to identify nomenclature of syntaxa (Janišová 2007). Nomenclature of syntaxa for phytosociological releves of forest communities were determioned on the base of species composition according to dominant, co-dominant and characteristic species that appear in certain ecosystem (Ružičková et al. 1996).

Processing of data is represented by historical analysis (evaluation of development and changes of forest edge lines in three different time horizons), identification of forest edge types, evaluation of species diversity and growth forms. To evaluate species diversity we have chosen from the group of indexes of species richness - index $\mathrm{N}_{0}$ (Hill 1973), Shannon's index H' (Shannon and Weaver 1949), and index E5 (Hill 1973). Single diversity indexes of all zones in the area of linear transectwere $\mathrm{c}$ with the help of TurboWin programme (Hennekens 2001). We evaluated species diversity for certain types of forest edges. Growth forms were described according to Raunkier (1905 In Jurko). To evaluate phytosociological releves we used JUICE (Tichý 2002) and CANOCO software (Ter Braak and Šmilauer 1998).

\section{RESULTS}

\section{Development of forestation in researched localities}

The described village developed at the beginning of the $18^{\text {th }}$ century from coal settlements of the Mining Chamber. The structure of forest growth was influenced by 400 years lasting activities of woodcutters and charcoal burners that supplemented these activities with sheep and goat grazing. Parts of former forest growth have been re-forested with spruce cultures that significantly differed from the original species, mostly rich beech and fir forests (Eu-Fagenion p.p. maj.) (Michalko 1986). Parts of former forests have been deforested and used as mowed and grazed areas. After decline of mining activities in the area of the Staré Hory village and Revúca by the end of the $18^{\text {th }}$ century and at the beginning of the $19^{\text {th }}$ century inhabitants started to drift in cities nearby. At the beginning of the $20^{\text {th }}$ century the area started to become a tourist centre. It led to development of many recreational facilities in previous years (the growth of these facilities went up to $391 \%$ ). Part of grassland and pastures has been used for recreational activities. Group of forest vegetation and grassland elements in the evaluated area has dominant position, but their ratio has changed dramatically (Fig. 2). In first two time periods there was dominance of grasslands and intensively used pastures (58.5\% in 1949 and $46.2 \%$ in 1961). In 2007 there was dominance of forests ( $53 \%$ of this area) a grasslands represented only $33.5 \%$ of the area. The lenght of forest edges declined roughly by $3 \mathrm{~km}$ (nowadays it represents 30.4 $\mathrm{km}$ ). The area nowadays is of a mosaic structure of forested land and grasslands (used also as ski areas during winter). 
Fig. 2: Changes of land-use forms and forest edge lines in the area of Donovaly village between 1949 - 2010 and position of transects (According to Škodová, 2010)

1949

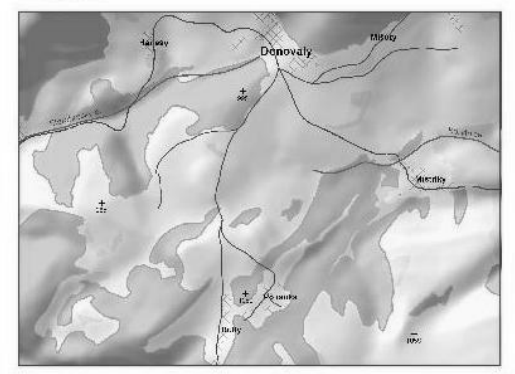

2010

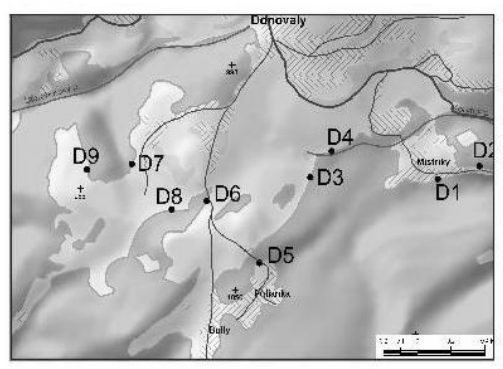

1961

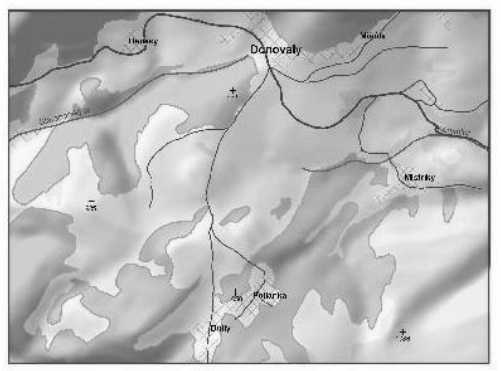

Legend

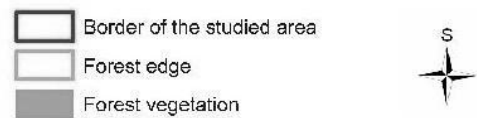

Non-forest woody vegetation

Grasslands

Rock and substrate

38.8. Residential and recreational areas

- Transport

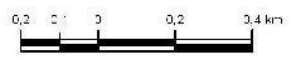

\section{Character of forest edge community}

Forest edges as ecotone communities represent the mix of various phytocoenoses. To find, which ecosystems are connected, we classified forest area, growth mantle and grass area to certain phytosociological units of different types (Janišová 2007, Ružičková et al. 1996). In the range of grasslands in nine releves we recorded 101 species of vascular plants (97 herbs and 4 trees). We identified communities of Nardo strictae-Agrostion tenuis (K. Ujházy, J. Kliment) that in succession overgrown with Vaccinium myrtillus and trees (transects D1, D7, D9). On nitrified areas of alluvial plain of bog type (transect D2) we identified Chaerophyllo hirsuti-Filipenduletum ulmariae Niemann et al. 1973, from Calthion palustris (P. Hájková) and class Molinio-Arrhenatheretea Tüxen 1937. The majority of grasslands among the villages of Donovaly, Mistríky and Bully also belongs to this group (transects D3, D4). It is represented mostly by Arrhenaterion elatioris Luquet 1926. In some areas it is separated by Violo sudeticae-Agrostietum capillaris, Nardo strictae-Agrostion tenuis Sillinger 1933 (transect D5, D6, D8). Scrub mantel did not occur in any of the monitored transects. In growth mantel zones of nine transects we identified 110 species of plants (13 species of trees and a 97 species of herbs). It consisted dominant species of forest (Picea abies, Fagus sylvatica). On nine releves of forest overgrow we identified 33 species of vascular plants ( 9 trees and 24 herbs among them). On acid soils, as podsols (transects D1-D5, D7, D8) originally occurred Piceion excelsae in Pawlowski et al. 1928 that was replaced by spruces (Picetum culti) with undergrowth of oligotrophic and acid types. We monitored also ferns, Vaccinium myrtillus. On carbonate base (transects D6, D8) appeared species such as Eu-Fagenion Oberd. 1957, usually on rendzic leptosols with cambic subtype. Fagus sylvatica also with admixture of Picea abies represent the dominant species. 


\section{Types of forest edges}

Abiotic variables differences and anthropic influence determined distinctiveness in the structure and species variability of forest edge vegetation. Upper and side type of forest edge dominates. In monitored areas we defined three types of horizontal and vertical structure:

Type A The edge of forest comprises of deciduous and mixed growths with thickly branched tress with the occurrence of shrubs in growth zone (transects D6, D8),

Type B The edge of forest comprises of thickly branched coniferous trees with the unique occurrence of shrubs in growth zone (transects D1, D3, D5, D7, D9),

Type C The edge of forest comprises of loosely and thickly branched coniferous trees and herbaceous bordering withwet grasslands (transects D2, D4).

\section{Structure and species diversity of forest edges}

Structure and species diversity of forest edges are indicators of landscape diversity. Following recent trends forests edges represent very important areas of forest fragmentation with a big potential of raising species diversity. In 27 records we identified 152 species. Species with frequency over $8 \%$, such as Achillea millefolium, Veronica officinalis, Veronica chamaedrys, Festuca pratensis, Dactylis glomerata and Sillene nutans based on DCA analyses represent the dominants of non-forest zones, Rubus idaeus, Rosa canina agg., Avenella flexuosa represent growth mantel and Fagus sylvatica, Picea abiesand Oxalis acetosella represent forest community (Fig 3).

Fig. 3: DCA analyses outputs - Releves classed to forest edge zones and species with frequency over $8 \%$.

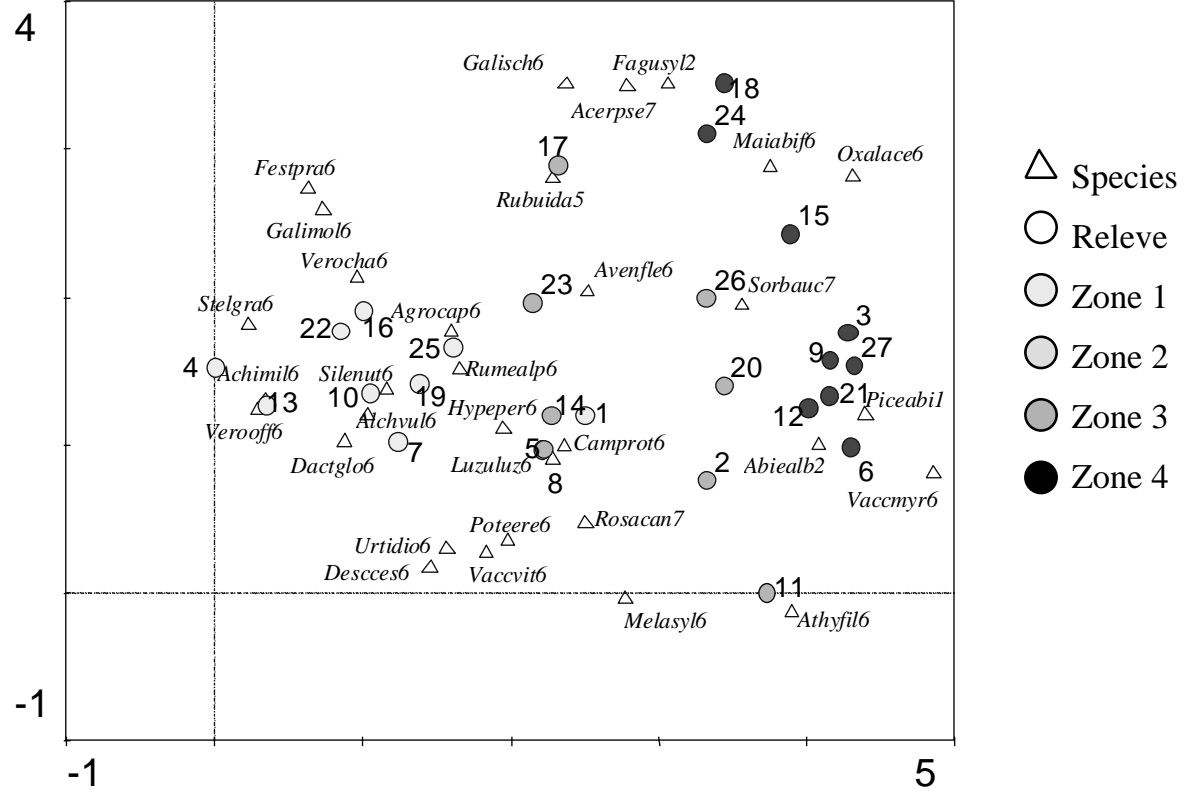

Note: Zone 1- grasslands, Zone 2 - herbaceous mantle, Zone 3 - growth mantle, Zone 4 - forest, labels represents genus and species name. Data in computation are extracted (According to Škodová, 2010). 
When analyzing species diversity of certain forest edges (Fig 4) the highest number ofspecies in A a B forest edges types was recorded in the growth mantle (29-35 species) and in type $\mathrm{C}$ in herbaceous edge there were 27 species found. Non-forest zones of transects and also forest zones do not contain so many species. It is result of the „edge effect"representing the incline ofspecies numbers in forest edge zones. The value of $\mathrm{H}^{\prime}$ and E5 indexes have very similar process, only in B type of forest edge the value of $\mathrm{H}^{\prime}$ index in direction of non-forest edge towards the forest has a tendency to decline. It shows the domination of some species in growth mantel of the forest.

\section{Fig. 4: Species diversity graphs of different types of forest edge.}
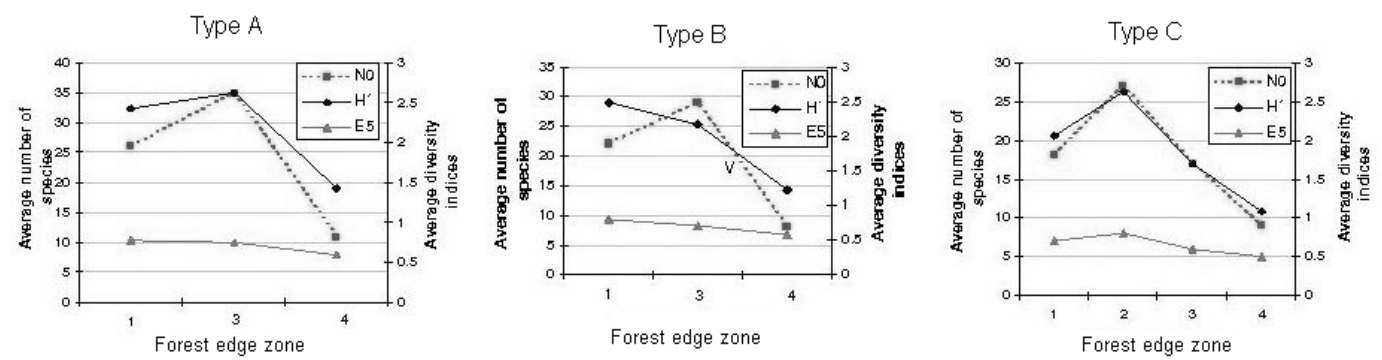

Note: $\mathrm{N}_{0}$ - Species richness, $\mathrm{H}^{\prime}$ - Shannon index, E5 - Index E5 (According to Škodová, 2010).

\section{Forest edge growth forms of vegetation}

One of plant community signs is the representation of plant growth forms that is the result of habitat conditions, land use and relations between plant populations. Percentages cover of live forms in certain zones of forest edge have been computed from coverage of species. Average values in concrete forest edge zones are shown in graphs. It is clear that in the zone of grass grown dominate hemikryptophyts, in the percentage from $70 \%$ to $97 \%$ (87\% average). In the zone of herbaceous mantle hemikryptophyts have clear domination. In the zone of growth mantles of deciduous and mixed forests we can easily find all live forms vertically divided into layers. In coniferous forest growth mantels nanophanerophyts do not represent the main part. Phanerophyts dominate inside the forests. Appearance of other forms depends on engagement consistence of phanerophyts. In coniferous forests chamaephyts is represented mostly by Vaccinium myrtillus. Hemikryptophyts represented by increasing percentage of chamaephyts, geophyts and nanophanerophyts is characteristic for succession of grassland plants.

\section{DISCUSSION}

Forest ecotone complex represents ecologic gradient of various ecologic factors (Pietzarka and Roloff 1993). Individual forest ecotone types have as space units various interior structure, various space attributes and other characteristics that are caused by variuos non-biotic and biotic factors. They are also influenced by time, development and their function (stability, permeability, elasticity) (Šindelár 2002, Rajnoch 1989). In individual zones of forest ecotone it is possible to find different non-biotic conditions, represented by variuos species structure (Ries et al. 2004, Harper et al. 2005). There are only few studies with the focus on structure and species variability of forest edges (Guirado 2006). Many observations (Forman and Godron 1993, Otto 1994, Temple and Flaspohler 
1998, Batáry and Báldi 2004, Sklenička and Šálek 2005, Laurance 2008) show that forest edges (ecotones) are characterized by obvious increase of flora and fauna species diversity in comparison to natural forest landscape. The change of forest diversity can be understood as a change of vegetation along ecological gradient which is linear (Whittaker 1967). Some studies (Cadenasso and Pickett 2001, Godefroid and Koedam 2003, Pauchard and Alaback 2004) show non-linear reactions of forest richness and composition of vegetation in connection to distance from forest edge. This conclusion is stressed also by results of Pietzarka and Roloff (1993). Our research shows the same fact.

Significantly large forest edges mostly form at natural edges. They are ecotones among forest growth and water flows or water surface, peat bogs, rocky steppes, on transition of forest to arid or saline zone (Jeník 1992, Soukupová et al. 2002). Anthropogenic edges are more narrow. Depending on ecological variables of theenvironment and the influence of man, they can be of various forms - from gradual transition to sharp, almost discontinuous gradient (Balcerkiewicz 1992, Kilianová et al. 2009). Older (larger) edges show continual (abrupt), sudden change of species diversity. With respect to spruce monocultures (typical in the locality of Donovaly) and on wind exposed localities, there are significantly sharper edges and decrease in species diversity in the direction from deforested area to forest. This type of edge demonstrates gradual decrease in number up to the absence of the species of herbaceous level. Their continual character results from the fact that the occurrence of individual species is gradual - corresponding with their requirements and competitiveness (Dierschke 1974, Zerbe and Roweck 1991). Young edges show a sudden change in species diversity. In spruce monocultures (typical for the site Donovaly) and wind exposed locations there are sharp edges ecologically disadvantageous (Geiger 1961, Pietzarka 1996, Costa 2001). They are of discontinuous character and the coverage of mostly herbaceous species suddenly decreases. This discontinuum emphasizes the barrier effect of forest edge on species proliferation (Mader and Pauritsch 1981, Yahner 1988, Jedicke 1991, Šindelár 2002).

\section{CONCLUSION}

The existence and the maintenance of forest edge are decided by the mechanism and factor of their origin; i.e. human activity, its intensity and the length of impact. Predominantly forested land of Starohorské Mountains is typical for its significant dynamics of forest growth during last centuries that specifically relates to mining and grazing. All these factors resulted in the fragmentation of originally continuous forest growth and the introduction of anthropogenic forest edges that currently represent a significant part of forest area. It is necessary to pay close attention to forest edges, a biologically specific phenomenon with a specific concentration of flora and fauna species and landscape function. As the ecosystems of forest edges have not been a priority of scientific interest so far, this paper represents our contribution to the research of this segment and to the management of landscape.

In this study we describe three types of ecotones of horizontal and vertical structure. From the results of our research there is a clear tendency to high diversity of living spaces in forest edge. Continuously occur species of forest, non-forest and marginal biotopes. Our research proves the "edge effect", which represents the increase of the number of species in forest edge zones (type A increases by $53 \%$, type B increases by $48 \%$, and type C increases by $59 \%$ compared to neighbouring ecosystems). In the zone of growth mantles of 
deciduous and mixed forests, we can easily find all live forms vertically divided into certain layers. Phanerophytes do not occur in the growth mantles of coniferous growth.

We analysed phytosociological data with the use of unimodal ordinance method, and we tried to find out their correlation with the parameters of environment. In DCA analysis, the second axis of the largest variability of vegetation evenly correlates with several factors (rock, soil, the age of forest growth). Also according to the CCA analysis, the second ordinance axis mainly correlates with the character of substrate. The geologic subsoil of the part of locality consists of carbonate rock as limestone with locations of dolomites; elsewhere, varied slates, quartzy sandstone and conglomerates occur (Polák 2003), with which soils correlate and influence the variability of vegetation. The age of forest growth and the type of forest edge with respect to the form of relief also belong among significant factors. The remaining tested factors proved to be insignificant.

Based on historical analysis, it is possible to see the increase in residential and recreational premises (increase by $391 \%$ ). However, it is not to the detriment of forest growth, its area even increases, but to the detriment of grassland, specifically grazed land (decrease in area by $32 \%$ ). Based on the influence of intensive use of predominantly allochtonous spruce forest growth, the continuous grazing and mowing of ski slopes on the monitored territoryand the young, narrow edges of forest dominate (type B). The process of secondary succession only occurs on inaccessible localities. The expansive species of high grass and wood from the seedling age of surrounding growth are applied quite fast and to a larger extent. The reason of forest edges research is also their landscape ecological importance.

Forest edges are influencing nearby ecosystems and also stabilize their function in landscape of the country. With their high influence they form a landscape character and overall esthetics of the landscape.

\section{ACKNOWLEDGEMENT:}

This work is financially supported by the Grant Agency UGA UMB (grant No. 02/10/2009/2010)

\section{REFERENCES}

Balcerkiewicz, S., Kasprowicz, M. \& Pietrzak, M. (1992). Landscape-geobotanical basis for a typology of the man-made forest boundary, Ecology (ČSFR), 1: 29-47.

Batáry, P., Báldi, A. (2004). Evidence of an edge effect on avian nest success: a metaanalysis. Conservation Biology, 18: 389-400.

Braun-Blanquet, J. (1964). Grundzüge der Vegetationskunde. Pflanzensoziologie, 3. Springer-Verlag, Wien, p 866.

Cadenasso, M. L.,. Pickett,. S. T. A. (2001). Effects of edge structure on flux of species into forest interiors. Conservation Biology, 15: 91-97.

Costa, R. (2001). Waldrand - Liebensraum Voller Überraschngen. Servetsch Forestal dal Grischun, 7. Faktenblatt, pp 1-11. Accessed June 2006, from http://www.wald.gr.ch/ dowvload/waldrand.pdf

Dierschke, H. (1974). Saumgesellschaften im vegetations- und Standortsgefälle an waldrändern. Göttingen. 
Forman, R.T.T., Gordon, M. (1986). Landscape ecology.Wiley, New York, 620 p.

Gajdoš, A. (2005). Fyzickogeografická štruktúra krajiny Starohorských vrchov. Geografické štúdie, 11, FPV Univerzita Mateja Bela, Banská Bystrica, p 81.

Geiger, R. (1961). Das Klima der bodennahen Luftschicht. Vierte AuJage. Braunschweig, Friedrich Vieweg und Sohn, $646 \mathrm{p}$

Godefroid, S., Koedam, N. (2003). How important are large vs. small forest remnants for the conservation of the woodland flora in an urban context? Global Ecology and Biogeography, 12: 287-298.

Guirado, M., Pino, J. \& Rodà, F. (2006). Understorey plant species richness and composition in metropolitan forest archipelagos: Effects of forest size, adjacent land use and distance to the edge. Global ecology and biogeography, 15: 50-62. Accessed January 2011, from http://onlinelibrary.wiley.com/doi/10.1111/j.1466-822X.2006.00197.x/full

Harper, K.A., Macdonald, S.E., Burton, P.J., Chen, J.Q., Brosofske, K.D., Saunders, S.C., Euskirchen, E.S., Roberts, D., Jaiteh, M.S. \& Esseen, P.A. (2005). Edge influence on forest structure and composition in fragmented landscapes. Conservation Biology 19: 768-782.

Hennekens, S. M., Schaminée, J. H. J. (2001). TURBOVEG, a comprehensive database management system for vegetation data. In: Bruelheide, H. (Ed.): Journal of Vegetation Science 12, pp 589-591.

Hill, M.O. (1973). Diversity and evencess: a unifying notation and is consequenses. In: Ecology 54(2): 427-432.

Janišová, M. (2007). Travinnobylinná vegetácia slovenska - elektronický expertný systém na identifikáciu syntaxónov. Botanický ústav SAV, Bratislava, p 263.

Jedicke, E. (1991). Biotopverbund im Forst. Allgemeine Forst Zeitschrift 46 (14), pp. 703 705.

Jeník, J. (1992). Ecotone and ecocline: Two questionable concepts in ecology. Ecology (ČSFR), Bratislava, 11: 243250.

Laurance, W.F. (2000). Do edge effects occur over large spatial scales? Trends in Ecology and Evolution 15, pp 134-135.

Mader, H. J., Pauritsch, G. (1981). Nachweis des Barriere-Effekts von verkehrsarmen Straßen und Forstwegen auf Kleinsäuger der waldbiozönose durch Markierungs- und Umsetzungsversuche. Natur und Landschaft 58, pp 451-454.

Michalko, J. (1986). Geobotanická mapa ČSSR, čast’ SSR. 1 : 200 000, SSR, SAV, Veda, Bratislava, - Map sheets Brezno, Prievidza.

Otto, H. J. (1994). Walkdökologie. Verlag E. Ulmer, Stuttgard, p 391.

Pauchard, A., Alaback, P.B. (2004). Influence of elevation, land use and landscape context on patterns of alien plant invasions along roadsides in protected areas of south-central Chile. Conservation Biology, 18: 1-11.

Kilianová, H., Pechanec, V., Lacina, J. \& Halas, P. (2009). Ekotony v současné krajině. Analýza a modelování ekotonů v povodí Trkmanky. Univerzita Palackého v Olomouci, p 168.

Pietzarka, U., Roloff. A. (1993). Waldrandgestaltung unter Berücksichtigung der natürlichen Vegetationsdynamik. Forstarchiv 64, pp 107-113.

Pietzarka, U. (1996). Lebensraum Waldrand. Merkblätter waldökologie, Nr.2, Accessed November 2009, from http://www.fva-bw.de/publikationen/merkblatt/mb_48.pdf 
Polák, M. (2003). Vysvetlivky ku geologickej mape Starohorských vrchov, Čiert’aže a severnej časti Zvolenskej kotliny. 1:50 000,Vydavatel'stvo Dionýza Štúra, Bratislava, p 218.

Rajnoch, M. (1989). Význam lesních ekotonů pro stabilitu krajiny. Záhradníctvo č.1, pp 34-35.

Raunkiaer, C. (1905). Types biologiques pour la géographie botanique. In: Jurko, A. (Ed.), Ekologické a socioekologické hodnotenie vegetácie. p 195. Príroda, Bratislava,

Ries, L., Fletcher, R.J., Battin, J. \& Sisk, T.D. (2004). Ecological responses to habitat edges: mechanisms, models, and variability explained. Annual Review of Ecology Evolution and Systematics 35: 491-522.

Ružičkova, H. Halada, L., Jedlička, L. \& Kalivodová E. (1996). Biotopy Slovenska. Ústav krajinnej ekológie SAV, Bratislava, p 192.

Shannon, C. E., Weawer, P. (1949). The Mathematical Theory of Communication. Warren Weaver. University of Illinois Press, Urbana, Illinois. Reprinted (and repaginated) 1963.

Sklenička, P., Šálek, M. (2005). Effects of forest edges on the yield of silage maize. Die Bodenkultur. 56(3): 109-116.

Soukupová, L., Jeník, J. \& Frantík, T. (2002). Edge effect of krummholz in Giant Mts.' tundra, the Sudetes. Opera Corcontica. 38: 77-88. Vrchlabí,

Šindelár̆, J. (2002). Lesni a porostni okraje z hlediska lesního hospodářství, ochrany prírody a krajiny. Zprávy lesníckeho výskumu, svazek 47, č. 1, pp 34-39.

Škodová, M. (2010). Antropické okraje lesov v Starohorských vrchoch. Dissertation, Comenius University in Bratislava, Faculty of natural sciences, p 167.

Temple, S. A., Flaspohler, D. J. (1998). The edge of the cut. Implications for Wildlife Populations. Journal of Forestry, pp 22-26.

Ter Braak, C.J.F., Šmilauer, P. (2002). CANOCO Reference manual and CanoDraw for Windows User's guide. Sftw. for Canonical Community Ordination (version 4.5), Microcomputer Power, Ithaca, p 352.

Tichý, L. (2002). JUICE, software for veg. classification. Journal of Vegetation Science 13, pp 451-453.

Whittaker R. H. (1967). Gradient analysis of vegetation. Biol. Rev. 42: 207-264.

Yahner, R. H. (1988). Changes in wildlife communities near edges. Conserv. biol. 2, pp 333-340.

Zerbe, S., Roweck, H. (1991). Waldränder in der Kulturlandschaft. Naturschutz u. Landschaftsplanung, pp 186-191. 